\title{
Paradigma Humanis dalam Pelayanan Publik
}

\author{
Tunggul Prasodjo \\ Dosen STISIP 17-8-1945 Makassar \\ e-mail: tunggul.prasodjo@gmail.com
}

\begin{abstract}
ABSTRAK
Tulisan ini bertujuan menjelaskan implementasi pelayanan publik dewasa ini dari perspektif/paradigma humanistis. Metode yang digunakan adalah metode deskriptif, yaitu menggambarkan beberapa kajian, kebijakan pelayanan publik dari berbagai literatur. Hasil kajian literatur menunjukkan bahwa pendidikan karakter dan penanaman nilai-nilai humanisme kepada para pelaksana pemberi layanan (elit pemerintahan/politik, aparatur birokrasi) sangat penting dan harus dilakukan agar proses pelayanan publik dapat lebih berkualitas dan memberi kepuasan optimal bagi para penerima layanan.
\end{abstract}

Kata Kunci: Paradigma, humanis, pelayanan publik.

\begin{abstract}
This paper aims to explain the implementation of public service today from a humanistic perspective / paradigm. The method used is descriptive method, that is describes some study, public service policy from various literatures. The results of the literature review indicate that character education and the cultivation of humanism values to service providers (government / political elites, bureaucratic apparatus) are very important and should be done so that the public service process can be more qualified and provide optimal satisfaction for the recipients.
\end{abstract}

Keywords: Paradigm, humanist, public service.

\section{PENDAHULUAN}

Aturan dalam kehidupan bermasyarakat ada yang bersifat tertulis dan ada pula (lebih banyak didalamnya) yang tidak tertulis, dan sudah menjadi bagian dari kebiasaan yang berlaku sehingga menjadi aturan tersendiri. Apa yang disebut sebagai custom merupakan bagian dari aturan yang tidak tertulis itu. Sedangkan aturan yang tertulis sering disebut sebagai aturan yang administratif, dengan sifatnya yang birokratis. Aturan yang tertulis, umumnya merupakan bentukan dari sebuah birokrasi yang dibuat oleh siapa yang mengeluarkannya (lembaga, perkumpulan, atau pun pemerintah), sehingga prosesnya harus sesuai dengan rezim yang ditetapkan oleh masing-masing institusi yang membuat aturan. Apabila demikian, maka yang perlu menjadi perhatian adalah bagaimana seharusnya antara yang membuat peraturan dengan yang diatur dapat saling memahami tugas dan fungsinya dengan baik, dapat terwujud komunikasi timbal balik yang lancar, sehingga dalam prosesnya dapat terwujud pelaksanaan 
aturan atau administrasi publik dengan sebaik mungkin. Dalam kaitannya dengan birokrasi pemerintah, misalnya, disadari bersama bahwa pada hakekatnya pemerintah merupakan pelayan publik (sesuai dengan publik yang membutuhkannnya). Agar pelayanan kepada publik dapat lebih fungsional, maka birokrasi perlu netral (Sinambela, 2013:30).

Salah satu pendekatan atau paradigma untuk mempermudah pelayanan birokrasi yang profesional adalah dengan menggunakan pendekatan yang manusiawi, atau apa yang disebut dalam tulisan ini sebagai paradigma humanis. Paradigma humanis dapat diberi makna bahwa seseorang dalam memperlakukan orang lain harus memperhatikan sisi kemanusiaan dari orang, kelompok, atau masyarakat itu. Artinya apabila individu atau kelompok menjadi bagian dari administrasi negara (publik), maka dalam memberikan pelayanan harus pula memperhatikan sisi humanis dari masyarakat yang dilayaninya.

Setidaknya apabila konsep humanis dalam birokrasi tersebut dijalani dengan baik, akan muncul sebagai bagian dari administrasi modern yang ideal. Tipe administrasi modern ideal ini oleh Weber, dalam Prasodjo (2016:48), diidentifikasi dengan ciri-ciri sebagai berikut): 1) kegiatan birokrasi dilaksanakan secara teratur dengan batas-batas otoritas yang jelas, 2) ada hirarki kewenangan, 3) ada aturan yang jelas tentang perilaku, otoritas, dan tanggung jawab pegawai, dan 4) pegawai direkrut atas dasar merit sistem, bukan atas dasar ikatan kekerabatan.

Pertanyaannya kemudian, apakah implementasi pelayanan publik saat ini sudah seperti ekspektasinya? Menjawab pertanyaan ini tentunya memerlukan pemahaman yang komprehensif sehingga persoalannya dapat dilihat dari segala sisi. Dan jawabannya pun akan sangat bergantung dari perspektif mana pertanyaan tersebut diajukan. Widyastuti dalam Hasjimzum (2014:446) mengatakan bahwa selama ini ada anggapan dan kesan bahwa penyelenggaraan pelayanan publik adalah monopoli pemerintah, masyarakat dilibatkan hanya pada saat pemerintah membutuhkan informasi dari masyarakat.

Sejalan dengan anggapan di atas, Ruli Isa dalam Hasjimzum (2014:446) menjelaskan bahwa keluhan-keluhan masyarakat tersebut merupakan indikator bahwa pelayanan yang diberikan belum memenuhi harapan masyarakat. Kemampuan sebuah organisasi dalam menemukenali kebutuhan publik adalah dengan memperhatikan aspirasi publik dalam menerima pelayanan, yang kemudian direalisasikan dalam bentuk kebijakan dan/atau kegiatan. Prosedur pelayanan dinilai dengan adanya saluran komunikasi atau cara untuk menampung keluhankeluhan publik.

Pandangan di atas tentunya tidak berdiri sendiri, karena kondisi pelayanan publik di Indonesia masih diwarnai oleh prosedur pelayanan yang berbelit, akses yang sulit, biaya yang tidak transparan, waktu penyelesaian yang tidak jelas, dan menjamurnya praktik pungutan liar dan suap yang tidak jelas. Pelayanan publik di kantor-kantor pemerintah di Indonesia masih terbilang buruk. Berdasarkan hasil survei yang dilakukan Bank Dunia, dari 157 negara yang disurvei, Indonesia berada di urutan 135 dalam kualitas pelayanan publik (Serfianus dkk., 2014).

Berangkat dari gambaran di atas, sudah selayaknya terdapat solusi yang tentunya harus dianalisis dari akar permasalahannya. Tentu banyak sekali tawaran untuk memberikan saran dan masukan dari permasalahan-permasalahan tersebut, baik berdasarkan kajian teoritis/akademis maupun dari pengalaman perorangan yang terlibat langsung didalamnya. Namun bagaimana 
pun tetap harus diberikan tekanan bahwa selama itu baik untuk pengembangan pelayanan publik, semuanya dapat dijadikan acuan. Termasuk didalamnya apa yang akan penulis tawarkan di dalam tulisan ringkas ini.

\section{Pelayanan Publik yang Humanis}

Ndraha dalam Mustafa (2012:173) menjelaskan bahwa perilaku birokrasi memiliki ruang gerak antara perilaku soft dan perilaku hard yang "merupakan wujud interaksi antara individu dengan lingkungan birokrasinya, adalah bersentuhan dengan pelaksanaan fungsi pelayanan publik". Dengan kata lain, perilaku birokrasi yang diharapkan adalah perilaku yang profesional dalam mewujudkan aspirasi publik yang tercermin dalam pelayanan publik yang baik, sehingga akan meningkatkan kepercayaan publik kepada para penyelenggara pelayanan publik.

Dalam kaitan dengan paradigma humanis dalam penyelenggaraan pelayanan publik, Love Lock dalam Hasjimzum (450-451) menawarkan lima prinsip yang harus diperhatikan dalam pelayanan publik agar kualitas pelayanan publik dapat dicapai, yakni: 1) tangible, memberikan pelayanan yang baik yang ditunjukkan dengan perilaku pelayanan; 2) reliable, handal dan terampil, menguasai bidang kerja yang diterapkan; 3) responsiveness, rasa tanggungjawab terhadap kualitas pelayanan, maksudnya setiap pegawai dalam memberikan bentuk-bentuk pelayanan mengutamakan aspek pelayanan yang sangat mempengaruhi perilaku orang yang mendapatkan pelayanan; 4) assurance (jaminan), pelayan publik yang memiliki pengetahuan sehingga orang yang menerima pelayanan merasa puas dan yakin bahwa segala bentuk urusannya akan dapat diselesaikan dengan cepat dan benar; 5) emphaty, mampu melayani orang yang dilayani dengan penuh perhatian terhadap berbagai masalah yang membutuhkan pelayanan.

Empati tidak hanya ditunjukkan dengan perilaku dan bahasa tubuh, namun yang jauh lebih penting di dalamnya yaitu dapat menggunakan komunikasi yang baik dan tentunya mengandung unsur etika dan estetika. Karena itu, paradigma humanis dalam pelayanan publik salah satunya yang harus juga diimbangi adalah adanya komunikasi timbal balik yang efektif. Menurut Andi Wahyudi dalam Hasjimzum (2014:450), urgensi komunikasi dalam pelayanan publik memiliki peran yang sangat penting karena proses penyelenggaraan pelayanan publik dengan kelengkapan yang meliputi ketersediaan sumberdaya manusia, anggaran, biaya, sarana dan prasarana, serta metoda pemberian pelayanan, perlu dikemas dalam komunikasi yang baik antara provider dan pengguna layanan publik. Tanpa komunikasi yang baik, publik tidak mengetahui upaya apa yang telah dilakukan oleh provider layanan publik.

Lebih dari itu, menurut Kasmawati (2011:131), sebuah pelayanan dinilai sebagai pelayanan prima jika desain dan prosedurnya memenuhi beberapa prinsip, yaitu (1) mengutamakan pelanggan, (2) merupakan sistem yang efektif, (3) melayani dengan hati nurani, (4) melakukan perbaikan yang berkelanjutan, dan (5) memberdayakan pelanggan. Kaitannya dengan prinsip yang pertama, sedikit kita coba belajar dari psikologi perkembangan anak di dalam proses belajar. Seorang guru atau orang tua harus belajar memasuki dunia anak, bukan anak memasuki dunia guru atau orang tua. Demikian pula pelayan publik yang baik, harus berusaha hadir ke dunia yang dilayaninya tanpa harus keluar dari kodratnya sebagai pelayan publik yang profesional. 
Tunggul Prasodjo, Paradigma Humanis dalam Pelayanan Publik $\mid \mathbf{4 1}$

Satu hal yang perlu ditekankan lagi dalam pendekatan pelayanan publik yang humanis tidak lain adalah memberikan pendidikan dan pelatihan (diklat) kepada para penyelenggara birokrasi pemerintahan, termasuk pula didalamnya pendidikan karakter untuk menumbuhkan sikap humanis itu. Tanpa adanya pendidikan karakter dan penanaman nilai-nilai humanisme, proses pelayanan publik akan terkesan gersang.

\section{Pemimpin Pemerintahan yang Humanis}

Seorang pemimpin dalam pemerintahan negara harus bisa menyelenggarakan good governance, dengan mewujudkan cita-cita nasional sesuai dengan amanat Undang-Undang Dasar Negara Republik Indonesia Tahun 1945 (UUD 1945), yaitu "melindungi segenap bangsa Indonesia dan seluruh tumpah darah Indonesia, memajukan kesejahteraan umum dan mencerdasrkan kehidupan bangsa dan ikut melaksanakan ketertiban dunia" (Swasono, 2014: 3). Amanat UUD 1945 tersebut tentunya masih umum, namun tentunya masih perlu mendapatkan sentuhan yang sesungguhnya dalam tataran realitas sehingga cita-cita dasar tersebut dapat tercapai.

Apabila dianalisis lebih lanjut, good governance dengan paradigma humanis tersebut sesuai dengan amanat UUD 1945 di atas memiliki penjabaran dan maksud tersendiri. Dalam kaitannya dengan konsep "melindungi segenap bangsa Indonesia", misalnya, keberadaan pemimpin pemerintahan paling tidak harus mampu melindungi yang dipimpinnya dari kesengsaraan, kemiskinan, pengangguran, dan lain sebagainya, sehingga dapat meningkatkan kesejahteraan umum.

Pelayanan untuk meningkatkan kesejahteraan umum dari penyelenggara pemimpin pemerintahan dengan rezim yang ada di dalamnya tentunya sampai saat ini masih menjadi pekerjaan rumah yang cukup berat, hal ini tentunya tidak lepas dari perilaku pejebat negara yang tidak kenal malu "merampok kesejahteraan rakyat" dengan tindakan korupsinya. Meminjam istilah Sri-Edi Swasono (2014:5) bahwa rezim merampok negara telah meminggirkan kewajiban birokrasi negara untuk memajukan kesejahteraan umum. Sebagai catatan, dari 480 bupati/walikota se Indonesia, terdapat 300an bupati/walikota yang telah menjadi tersangka kasus korupsi (tidak termasuk jajaran-jajaran birokrasi lainnya di kalangan eksekutif, legislatif, yudikatif termasuk penegak-penegak hukum lainnya) (Harman, B. K., \& Sudirman, A, 2011). Disamping itu, apabila diamati secara cermat, terlihat bahwa kecenderungan rendahnya kinerja birokrasi pelayanan publik (khususnya pejabat pemerintah) dipengaruhi oleh budaya paternalisme yang masih kuat yang mendorong pejabat birokrasi untuk lebih berorentasi pada kekuasaan daripada pelayanan, menempatkan dirinya sebagai penguasa, dan memperlakukan para pengguna jasa (publik) sebagai objek pelayanan yang membutuhkan bantuannya (Maani, 2005:28).

Lebih jauh dijelaskan oleh Abdulwahab dalam Maani (2005:28) bahwa rendahnya kinerja pemerintah disebabkan oleh sistem pembagian kekuasaan yang cenderung memusat pada pimpinan, sehingga bawahan yang langsung berhubungan dengan pengguna jasa sering tidak memiliki wewenang yang memadai untuk merespon dinamika yang berkembang dalam penyelenggaraan pelayanan. Kondisi yang demikian tentunya sampai saat ini masih banyak terjadi, terlebih lagi dibarengi dengan desentralisasi yang banyak disalahartikan dan juga salah diposisikan oleh penguasa. 
Potret birokrasi, baik pada kasus rezim merampok negara atau pun sentralisasi kebijakan oleh pemerintah, merupakan potret penyelenggaraan birokrasi yang rapuh dari seorang pemimpin yang tentunya masih sangat jauh dari kata mampu menjalankan good governance yang memanusiakan manusia.

Bercermin dari apa yang ditunjukkan oleh kebanyakan pemimpin saat ini dalam menjalankan pemerintahan, masyarakat semakin memiliki kepercayaan yang tipis dan semakin kekurangan figur, sehingga potensi masyarakat untuk berkembang pun sulit digerakkan kalau tidak dengan usaha sendiri. Bagaimanapun kemajuan dari sistem pemerintahan yang dibangun oleh seorang pemimpin bergantung dari kemampuannya menggerakkan potensi secara efektif seluruh kekuatan masyarakat agar memiliki disiplin dan patuh terhadap kekuatan hukum yang berlaku, saling menghargai hak individu dan hak komunal yang dimiliki masyarakatnya (Irsan, 2014:41).

Seiring dengan adanya kebijakan desentralisasi (otonomi daerah) yang digulirkan pada 1 Januari 2001, sebagai perwujudan dari amanat Undang-Undang (UU) Nomor 22 Tahun 1999 tentang Pemerintahan Daerah (yang kemudian direvisi dan/atau diubah beberapa kali, terakhir dengan UU Nomor 9 Tahun 2015 tentang Perubahan Kedua Atas UU Nomor 23 Tahun 2014 tentang Pemerintahan Daerah), yang telah memberikan perluasan kewenangan kepada pemerintah daerah, maka pemerintah daerah mau tidak mau harus mampu melaksanakan berbagai kewenangan yang selama ini dilaksanakan oleh pemerintah pusat, seiring dengan pelayanan yang harus disediakan. Terkait dengan hal ini, Smith dalam Maani (2005:27) menjelaskan bahwa salah satu cara untuk mendekatkan pemerintah kepada masyarakatnya adalah dengan menerapkan kebijakan desentralisasi. Namun upaya desentralisasi akan menjadi masalah apabila pejabat politik dan/atau pejabat birokrasinya tidak profesional.

Terlepas dari persoalan tersebut, untuk menjadikan pemimpin politik atau pemerintahan yang humanis, tentunya harus mengikuti banyak petunjuk. Bagi pemimpin yang beragama Islam, misalnya, untuk menjadi seorang pemimpin yang mampu mendekati masyarakat dengan cara yang humanis tentunya tidak lepas dari contoh yang diberikan oleh Rasulullah Muhammad SAW. Hayat (2015:66) menjelaskan bahwa kepemimpinan Rasulullah terhadap berbagai perubahan dunia yang telah dihasilkan dan menjadi ikon penting bagi rakyatnya (umatnya) dalam keteladanannya, antara lain; (1) mampu menegakkan rasa keadilan; (2) memiliki rasa cinta, empati, dan simpati yang ditujukan kepada sesama umat manusia; (3) memegang teguh prinsip kejujuran; (4) menjunjung tinggi prinsip amanah; (5) memiliki kecerdasan dalam dimensi intelektual, emosional, dan spiritual; dan (6) bersikap transparan dalam setiap pelaksanaan tugas dan tanggungjawabnya.

Begitu juga dengan setiap pemimpin yang memiliki agama berbeda dapat prinsip kepemimpinan yang baik melalui agamanya masing-masing. Disamping ajaran agama dan konsep teoritis yang sangat bermanfaat, harus pula diperhatikan pemahaman sosial budaya, yakni seorang pemimpin itu menjalankan amanah kepemimpinannya. Dan yang penting, seorang pemimpin harus mampu melakukan perubahan-perubahan sesuai dengan perkembangan yang ada pada lingkungan masyarakatnya.

Perubahan-perubahan yang dapat dilakukan seorang pemimpin untuk meningkatkan kualitas pelayanan publik menurut Sanapiah (2005:22), antara lain:

1. Memangkas berbagai birokrasi yang sudah tidak relevan. 
2. Menerapkan contestability (membandingkan pelayanan yang dilakukan unit organisasinya dengan organisasi lain untuk melihat efisiensi dan efektivitasnya), bahkan mengembangkan kontrak dengan sektor swasta (jika hal ini merupakan jalan paling efektif dan efisien yang harus ditempuh).

3. Menggunakan berbagai teknologi baru untuk meningkatkan kualitas pelayanan publik. Mengembangkan kebijakan publik yang berorientasi kepada pelanggan (customer focus).

\section{Kepemimpinan Birokrasi Pemerintah Daerah dalam Pelayanan Publik yang Humanis}

Sangat penting untuk membedakan antara elit pemerintahan (politik) dengan aparatur birokrasi, yang tentunya akan bekerjasama dengan elit pemerintahan yang dipilih berdasarkan konsensus politik (pilkada/pileg). Akan tetapi, apabila diperhatikan, salah satu langkah yang sering dilakukan oleh elit pemerintahan yang baru menduduki tampuk kepemimpinan di institusi pemerintahan daerah, khususnya di institusi pemerintah daerah, adalah "rasionalisasi", yakni memfokuskan kebijakan pada perombakan besar-besaran formasi birokrasi. Mutasi juga dilakukan terhadap aparatur birokrasi yang dinilai memiliki kinerja kurang baik. Langkah tersebut tentu saja memicu ketegangan hubungan antara pemimpin pemerintah daerah yang dipegang elit politik dengan aparatur birokrasi dan masyarakat (Hadi, 2009:25). Lebih jauh dijelaskan bahwa ketegangan bisa terjadi karena pejabat politik yang baru ternyata lebih suka memasukkan aparatur birokrasi yang menjadi simpatisannya ke dalam atau yang dalam birokrasinya ketimbang mencari jajaran aparatur birokrasi terbaik dan profesional yang sudah ada dalam birokrasinya. Kondisi demikian disebut sebagai ciri dari model birokrasi patrimonial. Karakteristik dari birokrasi patrimonial adalah (1) para pejabat disaring atas dasar kriteria pribadi; (2) jabatan dipandang sebagai sumber kekayaan dan keuntungan; (3) para pejabat melakukan kontrol pada fungsi politik maupun fungsi administrasi; dan (4) setiap tindakan diarahkan oleh hubungan pribadi dan politik (Hayat, 2014: 72). Oleh sebab itu, setiap adanya pergantian tampuk kepemimpinan politik, aparatur birokrasi yang ada di dalamnya juga biasanya ikut berubah, hal ini umumnya dikemas dalam semboyan dan slogan "reformasi birokrasi". Adanya kecendrungan tersebut, dijelaskan oleh Hadi (2009:25) bahwa adanya slogan reformasi birokrasi di beberapa daerah ternyata tidak lebih dari sekadar menyingkirkan peran aparatur birokrasi yang tidak disukai dan mengokohkan peran aparatur birokrasi yang disukai. Akibatnya birokrasi tidak pernah dapat bekerja secara optimal dan profesional. Di sisi lain, aparatur birokrasi yang disokong elit-elit politik dari luar birokrasi ternyata juga berusaha melakukan kolusi dan pendekatan secara pribadi kepada pejabat politik yang baru untuk mengamankan jabatan atau menginginkan jabatan lain tertentu.

Merujuk pada permasalahan tersebut, apa yang perlu dilakukan elit pemerintahan untuk mengembangkan pelayanan publik yang humanis dan lepas dari adanya kepentingan pejabat politik, paling tidak harus memenuhi beberapa ciri seperti yang diuraikan Hadi (2009), sebagai berikut:

Pertama, harus responsif terhadap dinamika ekonomi, sosial, budaya, dan politik yang bergerak di tataran masyarakat daerah. konsekuensi dari adanya pemahaman tersebut tidak lain supaya para birokrat tidak lagi menganggap dirinya sebagai pejabat publik, namun sebagai pelayan publik. Hakikatnya adalah tatkala banyak aparatur birokrasi berkompetisi hendak 
menjadi pejabat, sesungguhnya mereka berkompetisi untuk menjadi "pelayan-pelayan" publik, dan bukan sebaliknya.

Kedua, munculnya jiwa pelayan mesti dimiliki oleh pucuk pimpinan birokrasi. Sebab itu, harus ada ketegasan para pimpinan birokrasi daerah, misalnya, menggunakan sebuah peraturan daerah (perda) atau keputusan kepala daerah yang mengatur bahwa aparatur birokrasi harus mulai mengubah kultur yang selama ini melekat pada diri mereka dengan kultur baru yang lebih mementingkan kepentingan publik.

Ketiga, salah satu yang dilupakan dalam pembelajaran untuk mendidik calon birokrat selama ini adalah penanaman "budi pekerti luhur", seperti budaya kejujuran, budaya kebaikan, budaya malu, budaya anti korupsi, budaya anti peminta-minta, dan seterusnya. Bila ternyata budaya penghambat itu tetap berpraktik, maka mesti ada sanksi moral yang diberikan kepada pelakunya. Sehingga pelayanan birokrasi tidak lagi menjadi penghambat dan dapat menghilangkan asumsi miring masyarakat bahwa tempat layanan publik bisa lancar apabila masyarakat menyodorkan "uang pelicin" atau sering disebut juga dengan istilah "uang rokok", "uang pulsa", "uang administrasi" atau juga "uang ucapan terima kasih", dan lain sebagainya.

Keempat, dibutuhkan figur kepemimpinan pemerintahan yang memiliki integritas kuat, memiliki karakter kuat, memiliki komitmen terhadap agenda reformasi birokrasi, serta berorientasi kepada kepentingan masyarakat luas. Figur kepemimpinan semacam itu dipercaya dapat membidani lahirnya budaya baru dalam jajaran birokrasi di daerah-daerah. Atas kepemimpinan birokrasi semacam itu, diharapkan aparatur birokrasi yang nakal tidak lagi mampu melakukan lobby untuk memperoleh jabatan tertentu.

\section{SIMPULAN}

Pengelolaan pelayanan publik tidak hanya sebatas pada adanya pemenuhan kepentingan antara yang melayani dan yang dilayani, namun lebih dari itu terdapat logika, etika, hukum, estetika, dan kebijakan-kebijakan lain didalamnya, sehingga siapapun yang memiliki tugas sebagai pelayan publik harus memahami falsafah dan prinsip pelayanan publik dengan baik, sehingga akan dapat melayani customer dengan cara yang manusiawi sesuai dengan kodratnya sebagai manusia yang memiliki jiwa yang diatur, baik oleh emosi, kultur, dan tentunya juga agama. Pelaksanaan pelayanan publik oleh elit pemerintahan, aparatur birokrasi, maupun pegiat administrasi publik/pemerintahan, harus memiliki sense of social yang tinggi sehingga pola kerjanya senantiasa berorientasi kepada kepentingan dan kebutuhan publik yang dilayani (customer oriented), yang tentunya lebih humanis dan dinamis.

\section{Daftar Pustaka}

Hadi, K. (2009). Kebijakan Birokrasi dalam Upaya Pelayanan Publik Berkualitas. Jurnal Unisia, Vol. XXXII (71).

Harman, B. K., \& Sudirman, A. (2011). Langkah-Langkah Strategis Memberantas Korupsi Di Indonesia. Masalah-Masalah Hukum, 40(4), 427-436.

Hasjimzum, Y. (2014). Model Demokrasi dalam Peningkatan Kualitas Pelayanan Publik (Studi Otonomi Daerah dalam Peningkatan Kesejahteraan Masyarakat Pasca Reformasi). Jurnal Dinamika Hukum, Vol. 14 (3). 
Hayat. (2014). Konsep Kepemimpinan dalam Reformasi Birokrasi: Aktualisasi Pemimpin dalam Pelayanan Publik Menuju Good Governance. Jurnal Borneo Administrator, Vol. $10(1)$.

Irsan, A. (2014). Merdeka \& Berdaulat: Catatan Kritis Diplomat RI yang Pernah Bertugas di Dua Negara Bekas Penjajah (1998-2006). Jakarta: Grafindo.

Kasmawati, A. (2011). Analisis Prinsip-Prinsip Good Governance dalam Penyelenggaraan Pelayanan Prima. Jurnal Humanis, Vol. XII (2).

Maani, K.D. (2005). Upaya Peningkatan Kualitas Pelayanan Publik di Era Otonomi Daerah. Jurnal Demokrasi, Vol. IV (2).

Mustafa, D. (2012). Potret Perilaku Birokrasi Pemerintahan. Suarlin (ed), Reformasi Birokrasi. Prosiding Seminar Nasional Administrasi Publik di Universitas Negeri Makassar.

Prasodjo, T. (2016). Strategi Pembangunan Kualitas Manusia: Suatu Perspektif Administrasi Publik. Jurnal Ilmu Administrasi Publik-UNM, Vol. 6 (2), $\quad 47$ - 54.

Sanapiah, A. (2005). Dimensi Kepemimpinan Aparatur dalam Perspektif Pelayanan Publik: Building The Trust. Jakarta: STIA LAN.

Serfianus, Djumlani, A, Paranoan, D.B. (2014). Perilaku Birokrasi Dalam Pemberian Pelayanan Publik (Studi pada Badan Koordinasi Penanaman Modal dan Perijinan Terpadu Kabupaten Nunukan). eJournal Administrative Reform, Vol. 2 (3), 1705 - 1718.

Sinambela, U.P. (2012). Revitalisasi Reformasi Birokrasi di Indonesia: Mewujudkan Netralitas Birokrasi dalam Pemerintahan. Suarlin (ed), Reformasi Birokrasi. Prosiding Seminar Nasional Administrasi Publik di Universitas Negeri Makassar.

Swasono, S. (2014). Krisis Kepemimpinan Rezim Merampok Negara. Yogyakarta: UST-Press. 